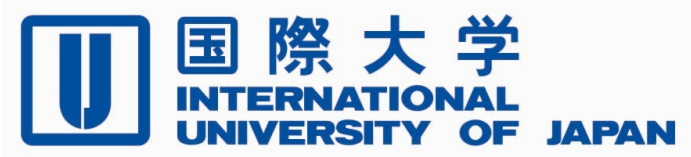

Economics \& Management Series

EMS-2013-14

\title{
Structural Changes and Interregional Income Inequal- ity in the Philippines, 1975-2009
}

Takahiro Akita

International University of Japan

Mark Saliganan Pagulayan

Alumnus 2013, International University of Japan

September 2013

IUJ Research Institute

International University of Japan

These working papers are preliminary research documents published by the IUJ research institute. To facilitate prompt distribution, they have not been formally reviewed and edited. They are circulated in order to stimulate discussion and critical comment and may be revised. The views and interpretations expressed in these papers are those of the author(s). It is expected that the working papers will be published in some other form. 


\title{
Structural Changes and Interregional Income Inequality in the Philippines, 1975-2009*
}

\author{
Takahiro Akita \\ International University of Japan \\ E-mail: akita@iuj.ac.jp \\ and \\ Mark Saliganan Pagulayan
}

The National Economic and Development Authority (NEDA), Philippines

\begin{abstract}
The Philippines has undergone gradual but substantial changes in industrial structure over the past few decades, and these have been associated with the changes in the geographical distribution of economic activity. This study analyzes changes in the determinants of regional income inequality in the Philippines associated with these structural changes from 1975 to 2009. This is accomplished by using the bi-dimensional decomposition method. The reduction of the disparity between the National Capital Region (NCR) and the rest of Luzon is essential to decreasing Luzon's high within-region inequality and overall interregional inequality. But this is not easy to accomplish, since services sectors have enjoyed agglomeration economies that NCR has nurtured under economic liberalization and globalization. Decentralization has been one way to ameliorate the disparity, but its effects are ambiguous. Another option would be to relocate some manufacturing activities to areas outside NCR where they could enjoy localization economies.
\end{abstract}

Keywords: structural change, regional income inequality, the Philippines, bi-dimensional decomposition, weighted coefficient of variation

JEL classification: O18, R11, R12

\footnotetext{
* An earlier version of the paper was presented at the $23^{\text {rd }}$ Pacific Conference of the Regional Science Association International in Bandung, Indonesia in July 2013. The authors would like to thank participants of the special session on the Spatial Dimension of Growth, Inequality and Poverty in Asia for their useful comments and suggestions. Takahiro Akita is grateful to the Japan Society for the Promotion of Science for its financial support (Grant-in-Aid for Scientific Research No. 24530274).
} 


\section{Introduction}

The Philippines, the second largest archipelagic country in the world with 7,100 islands, has grown at an average GDP growth rate of 3.4\% over the last three decades and a half, during which it has undergone gradual but substantial changes in its industrial structure. In 1975, the GDP share of the primary sector was 26\%, but has declined steadily to $20 \%$ in 2009 (Table 1). Unlike many other Asian countries, however, this has been accompanied by a fall in the share of the secondary sector, from $37 \%$ to $30 \%$. Particularly within the secondary sector, the share of manufacturing has declined significantly from $28 \%$ to $22 \%$. On the other hand, due to a rise in the shares of transportation, trade, finance and private services, the tertiary sector has raised its GDP share prominently from $37 \%$ to $50 \%$.

These structural changes were associated with the changes in the geographical distribution of economic activity (Table 2). Luzon, which includes the National Capital Region of Metropolitan Manila (NCR), dominates the country; in 1975, its GRDP share was $62 \%$, but has increased gradually to $65 \%$ in 2009 due solely to a rise in the share of NCR from $29 \%$ to $33 \%$. Meanwhile, Mindanao, which encompasses the two poorest administrative regions, i.e., the Autonomous Region in Muslim Mindanao (ARMM) and Caraga, has lowered its GRDP share from $21 \%$ to $18 \%$, while the GRDP share of Visayas has remained almost constant at around 16-17\%.

The Philippines has been known for its high level of income and expenditure inequality among Asian countries and around $15 \%$ of inequality in per capita expenditure is attributable to spatial inequality (Shorrocks and Wan, 2005). Thus, the Philippine government has been pursuing balanced regional development as a means to promote the overall development of the economy. However, large disparities still exist among regions and provinces in the Philippines. Table 3 exhibits that in 2009, only four out of 16 administrative regions, i.e., NCR, the Cordillera Administrative Region (CAR) and Northern and Southern Mindanao, have their per capita GRDP above the national average. NCR is by far the richest region with a per capita GRDP about 2.6 times the national average. This is more than double that of the next richest region 
(CAR) and 11 times that of the poorest (ARMM). Meanwhile, four poor administrative regions have their per capita GRDP less than a half of the national average in 2009.

What are the determinants of interregional income inequality in the Philippines? The present study is an exploratory research and attempts to investigate changes in the determinants of interregional income inequality over the period from 1975-2009 in the Philippines associated with the structural changes described above. Built on the earlier works of Akita and Miyata (2010) and Akita et al. (2011) for Indonesia, this is accomplished by the bi-dimensional decomposition method. The method decomposes interregional inequality in per capita GRDP simultaneously by regional groups and by GDP components (represented by industrial sectors) using the squared population-weighted coefficient of variation (squared WCV) introduced by Williamson (1965).

This study divides the period into four sub-periods (1975-1986; 1986-1991; 1991-2000; 2000-2009) to highlight several distinct episodes of development that the Philippines has experienced between 1975 and 2009. These include the fall of the Marcos regime in 1986, the start of decentralization in 1991 when the Local Government Code was introduced, the establishment of ARMM in Mindanao under the Ramos presidency in the middle of 1990s, ${ }^{1}$ the Asian financial crisis of 1997-98, the introduction of major trade liberalization policies in the $1990 \mathrm{~s}^{2}$ and intensifying globalization in the 2000s. These four sub-periods are termed, respectively, the period of Marcos' authoritarian rule, the post-Marcos/pre-decentralization period, the decentralization/Asian financial crisis period, and the post-Asian financial crisis period. To allow further dissection of interregional income inequality in the Philippines, the analysis is also performed with and without NCR due to its sizable share as indicated above.

There have been numerous studies on the distribution of economic well-being in the Philippines, reflecting continued interest in how development benefits are

\footnotetext{
1 ARMM was established in 1996 based on the Jakarta Accord between the Philippine government and the Moro National Liberation Front (MNLF) (Hill, Balisacan and Piza, 2007). ARMM, which has been plagued with a number of internal problems, is the poorest administrative region with its per capita GDP about a quarter of the national average.

${ }^{2}$ During the 1990s, nominal tariff rates on imports have been reduced substantially; the average nominal tariff rate has declined from $28 \%$ to $8 \%$ in this period (Tecson, 2007).
} 
distributed among different population subgroups and regions. ${ }^{3}$ Among them, the following studies analyzed interregional inequality in the Philippines: Manasan and Mercado (1999), Manasan and Chatterjee (2003), Balisacan and Fuwa (2003, 2004b), Mapa, Balisacan and Briones (2006), Balisacan (2007), Manasan (2007), and Mapa, Balisacan, Briones and Albis (2009). Manasan and Mercado (1999) adopted the neoclassical growth method advanced by Barro and Sala-i-Martin $(1992,1995)$ to investigate $\sigma$ - and $\beta$-convergence in per capita GRDP among 14 administrative regions for the period from 1975-1997 and found evidence for $\sigma$ - and $\beta$-convergence in the whole period. Manasan and Chatterjee (2003) extended the period to 2000 and obtained similar results for the period from 1975-2000. They found that the speed of $\beta$-convergence is faster in the sub-period from 1975-1986 than in the sub-period from 1986-2000, though the estimated $\beta$-coefficient for the latter sub-period is not statistically significant.

Balisacan and Fuwa $(2003,2004 b)$ also conducted a convergence analysis using the same neoclassical growth framework as in Manasan and Mercado (1999) and Manasan and Chatterjee (2003); but their studies were for the period from 1988-1997 and based on per capita expenditure data for 70 provinces from the Family Income and Expenditure Survey (FIES) rather than per capita GRDP data for administrative regions. Their studies found a high rate of absolute $\beta$-convergence for the study period and that provincial growth is positively associated with the initial land inequality and the implementation of the Comprehensive Agrarian Reform Program (CARP), while negatively associated with mortality rate and a proxy variable for political competitiveness. Balisacan and Fuwa (2004b) also estimated the contribution of spatial inequality to overall inequality in per capita expenditure based on FIES data for 1985, 1988, 1991, 1994, 1997 and 2000 and found that inequality among regions accounts for around $12-15 \%$ of overall inequality as measured by the Theil $\mathrm{T}$ index.

Built on the Balisacan studies, Mapa, Balisacan, Briones and Albis (2009) investigated the determinants of provincial income growth for the period from

\footnotetext{
3 See, for example, Estudillo (1997), Manasan and Mercado (1999), Mercado (2002), Manasan and Chatterjee (2003), Balisacan and Fuwa (2003, 2004a, 2004b), Mapa, Balisacan and Briones (2006), Balisacan (2007), Hill, Balisacan and Piza (2007), Manasan (2007), Tecson (2007), Balisacan, Hill and Piza (2008), Mapa, Balisacan, Briones and Albis (2009), Clausen (2010) and Capuno (2011, 2012).
} 
1985-2003. With the addition of the three new explanatory variables (proportion of young dependents, net in-country migration and spatial neighborhood effects), they found evidence for conditional $\beta$-convergence for the study period and that the proportion of young dependents, net migration, neighborhood effects and a locational dummy for ARMM provinces have a negative and significant effect on provincial growth, while expenditure inequality has a positive and significant effect on provincial growth, though up to a certain level of inequality.

This present study differs from these previous studies on interregional inequality in the following respects. First, it uses GRDP data for administrative regions over a long period of time, from 1975 to 2009. Second, it employs the bi-dimensional inequality decomposition method to analyze changes in the determinants of interregional income inequality associated with structural changes.

\section{Data and Method}

\subsection{The data}

This study measures inequality among administrative regions in the Philippines from 1975 to 2009 using GRDP by industrial origin at 1985 constant prices taken from the Regional Accounts of the Philippines compiled by the National Statistical Coordination Board (NSCB, various issues). In addition, population data from 1975 to 2009 are culled from various issues of the Philippine Statistical Yearbook (NSO, various issues).

To conduct a decomposition analysis by regional groups, this study divides all administrative regions into three island regions: Luzon, Visayas, and Mindanao. Luzon includes NCR, CAR, Ilocos, Cagayan Valley, Central Luzon, Southern Tagalog, and Bicol; Visayas comprises Western Visayas, Central Visayas, and Eastern Visayas; and Mindanao consists of Western Mindanao, Northern Mindanao, Southern Mindanao, Central Mindanao, ARMM, and Caraga. ${ }^{4}$ On the other hand, to perform a decomposition analysis by GDP components, this study uses 11 sectors. This is because the GRDP dataset provides information for 11 industrial sectors: 1) agriculture, fisheries

\footnotetext{
${ }^{4}$ In the dataset, CAR was created in 1987 in Luzon, while ARMM and Caraga were created, respectively, in 1995 and 1996 in Mindanao. Thus, in Luzon, there were 6 administrative regions before 1987, while in Mindanao, there were 4 and 5 administrative regions, respectively, before 1995 and before 1996.
} 
and forestry, 2) mining and quarrying, 3) manufacturing, 4) construction, 5) electricity, gas and water, 6) transportation and communication, 7) trade, 8) finance, 9) real estate, 10) private services, and 11) government services.

\subsection{Methodology}

In order to analyze structural changes and interregional inequality in the Philippines, this study employs the bi-dimensional decomposition method of the squared population-weighted coefficient of variation (squared WCV), which was developed by Akita and Miyata (2010). Its detailed derivation is relegated to the Appendix. Based on equation (A7) in the Appendix, the bi-dimensional decomposition method is summarized as:

$$
1=\sum_{i=1}^{m} \sum_{k=1}^{K} C W_{i k}+\sum_{k=1}^{K} C B_{k}
$$

where $m$ is the number of island regions and $K$ is the number of industrial sectors. $C W_{i k}$ is the contribution of the within-region inequality of GRDP component $k$ in island region $i$ to overall inequality, while $C B_{k}$ is the contribution of the between-region inequality of GRDP component $k$ to overall inequality. ${ }^{5}$ Since the economy consists of 3 island regions (Luzon, Visayas, and Mindanao) and 11 industrial sectors, there are 33 inequality components in the first term in equation (1) (3 island regions times 11 industrial sectors), while 11 inequality components in the second term (11 industrial sectors).

\section{Empirical Results}

\subsection{Trends in Interregional Income Inequality}

Figures 1 and 2 exhibit inequality in per capita GDP among administrative regions from 1975 to 2009 as measured, respectively, by the WCV and the Theil T and L indices. As mentioned above, NCR accounts for 33\% of total GDP in 2009, which is compared to its population share of $12 \%$; thus, it is by far the richest region with a per capita GDP about 2.6 times the national average and more than double that of the next richest region

\footnotetext{
${ }^{5}$ Within-region inequality implies inequality in per capita GDP among administrative regions within an island region (Luzon, Visayas or Mindanao), while between-region inequality means inequality in per capita GDP between the three island regions.
} 
(CAR). Due to NCR's huge contribution to the economy, there is a large difference in inequality between the inclusion and exclusion of NCR. If NCR is excluded from the data set, the levels of interregional inequality drop substantially.

Recognizing the need for a balanced regional development in the first sub-period from 1975-1986, the Marcos government had deliberately attempted to address disparity across regions through agriculture support, land tenancy, institution building, infrastructure development and industrial dispersal (Mercado, 2002). As a result, interregional inequality has declined gradually in the first sub-period with or without NCR, though there are some fluctuations when NCR is included. This sub-period, however, registered a relatively slow growth at an average annual growth rate of $2.4 \%$ (Table 2). In the second sub-period from 1986-1991, the country has moved away from dictatorial rule to democracy, paving the way for an improved economic performance. NCR accelerated its growth at an average rate of 5.3\%, which was much higher than the national average growth rate of $3.8 \%$. In spite of an effort to increase rural productivity, however, most southern regions have stagnated in comparison with their northern counterparts. With NCR included, interregional inequality has increased gradually in the second sub-period.

The third sub-period from 1991-2000 could be further subdivided into two sub-periods: early stages of decentralization (1991-1996) and the Asian financial crisis (1997-2000). Enacted in 1991, the Local Government Code (LGC) of the Philippines placed local governments at the forefront of administrative power. While the first three years of decentralization experienced a decrease in interregional inequality with or without NCR, the two succeeding years saw an increase, peaking in 1996 before the Asian financial crisis struck in 1997. In the crisis period from 1997 to 2000, interregional inequality dropped slightly with NCR, while substantially without NCR. Though the impact of the Asian financial crisis in the Philippines was not as severe as in some of its Asian neighbors, this decrease in inequality is similar to the case of Indonesia where the crisis sent the economy into contraction as a result of substantial capital flight and currency devaluation

The economy experienced a relatively high growth at an average annual growth rate of $4.5 \%$ in the fourth sub-period from 2000-2009, which is the highest among the four sub-periods. Particularly, NCR grew rapidly at 5.0\%. With its relatively slow population 
growth, this made its per capita GDP 2.6 times as large as the national average in 2009, up from 2.4 in 2000. When NCR is included, this sub-period experienced a significant increase in interregional inequality; interregional inequality attained the highest in 2008 whether it is measured by the WCV or the Theil indices. However, due in part to policies of economic integration through increasing regional interconnectivity, the rest of the country realized relatively balanced regional development; thus, when NCR is excluded, interregional inequality has been quite stable. Interestingly, a slight decline in inequality is observed from 2008 to 2009. This occurred at the time of the Global financial crisis in 2008, which affected the country similar to the Asian financial crisis of 1997-1999. It should be noted that the difference between the levels of overall interregional inequality calculated based on GRDP including and excluding NCR has expanded in the study period. But the expansion occurred mostly in the fourth sub-period, particularly in the period between 2001 and 2008, during which NCR's per capita GDP grew at an average annual rate of $4.7 \%$, which is compared to the national average growth rate of $3.1 \%$. This shows further spatial agglomeration of economic activities in NCR under intensifying globalization.

\subsection{Bi-dimensional Decomposition of Interregional Inequality by Regional Groups and GRDP Components}

Based on equations (A3), (A9) and (A10) in the Appendix, we first decompose interregional income inequality into within-region and between-region inequality components. The results are presented in Tables 4 and 5, which are based on GRDP including and excluding NCR, respectively. As the results do not qualitatively differ much whether the Theil indices or the squared WCV is used, we explain the results based on the squared WCV, hereafter.

When NCR is included, inequality within Luzon (Island Region 1) accounts for more than $80 \%$ of overall interregional inequality as measured by the squared WCV; thus, the trend pattern of overall inequality corresponds very closely to that of inequality within Luzon. Due in part to an increase in inequality within Mindanao (Island Region 3 ), the contribution of the within-region inequality component (first term in equation (1)) has risen since the middle of the 1990s when ARMM and Caraga were created. Conversely, the contribution of the between-region inequality (second term in equation (1)) has declined. In 2009, the within-region inequality component accounts for $92 \%$ of 
overall interregional inequality. It should be noted that inequality within Visayas (Island Region 2) has been very low and quite stable in the study period reflecting Visayas' relatively homogeneous development compared to Luzon and Mindanao; thus its contribution to overall inequality has been around 1-2\% when NCR is included.

When NCR is excluded, the levels of inequality within Luzon drop substantially. Since the 1990s, inequality within Luzon has declined gradually; its contribution to overall inequality has decreased to $34 \%$ in 2009 from $73 \%$ in 1991. It seems that without NCR, relatively balanced regional development has been achieved within Luzon since the Local Government Code was introduced in 1991, at least among administrative regions (Figure 3). Meanwhile, inequality within Mindanao has increased and its contribution has risen to $45 \%$ in 2009 from merely $12 \%$ in 1991 . But this is due in part to the establishment of two poor regions within Mindanao (ARMM and Caraga) in the middle of 1990s (Figure 3). It should be noted that between-region inequality has been declining gradually and its contribution to overall inequality amounted to merely $2 \%$ in 2009. This indicates that inequality between three island regions is attributable mostly to the disparity between NCR and other administrative regions.

The results of a bi-dimensional decomposition analysis are presented in Tables 6 and 7, which are based on GRDP including and excluding NCR, respectively. With NCR included, the contribution of the secondary sector to overall interregional inequality amounted to $63 \%$ in $1975 .{ }^{6}$ But since then, it has decreased prominently to $35 \%$ in 2009 , due mainly to a fall in the contribution of manufacturing and construction in Luzon (Island Region 1), particularly before the Asian financial crisis. Meanwhile, the tertiary sector has raised its contribution from $46 \%$ in 1975 to $75 \%$ in 2009 , owing to an increase in the contribution of transportation/communication, finance and private services in Luzon, particularly after the Asian financial crisis, offsetting a decrease in the contribution of manufacturing and construction in Luzon. This makes Luzon's contribution to overall inequality almost constant at around $83-85 \%$ in the study period.

The contribution of between-region inequality has declined to 8\% in 2009 from $14 \%$ in 1991; this is attributable mainly to a decrease in the contribution of manufacturing and construction. It should be noted that the primary sector in Luzon

\footnotetext{
${ }^{6}$ The contribution of a sector means the contribution of inequality in the spatial distribution of the sector's activities to overall interregional inequality.
} 
made a negative contribution to overall inequality due to NCR's zero-output record in agriculture and mining. In 2009, the manufacturing sector contributed most to overall interregional inequality at $32 \%$, which is followed by private services (19\%), finance $(18 \%)$, transportation/communication $(17 \%)$ and trade $(13 \%)$, which are compared to the corresponding figures of $50 \%, 11 \%, 8 \%, 7 \%$ and $10 \%$ in 1975 . These observations indicate an increasingly important role of the tertiary sector, particularly within Luzon, in the determination of interregional income inequality in the Philippines.

When NCR is excluded, the contribution of the secondary sector was $48 \%$ in 1975 , which is much smaller than the value when NCR is included (63\%). After increasing slightly to $52 \%$, it has declined to $43 \%$ in 2009 due to a fall in the contribution of manufacturing in Luzon, though the contribution of Mindanao's manufacturing has risen conspicuously to $13 \%$ from $4 \%$. Unlike the case where NCR is included, the contribution of agriculture to overall inequality was positive and high. Though it has decreased prominently in the study period, it was still $10 \%$ in 2009 due to a large contribution by Mindanao's agriculture. On the other hand, the contribution of the tertiary sector has risen gradually from $22 \%$ in 1975 to $45 \%$ in 2009 owing mainly to an increase in the contribution of trade and private services. This offsets a decrease in the contribution of agriculture.

It should be noted that Luzon's contribution to overall inequality was very high at $73 \%$ in 1991 even without NCR; but it has fallen substantially to $34 \%$ in 2009 due to a decrease in the contribution of agriculture, manufacturing and trade, while Mindanao's contribution has risen prominently from $12 \%$ in 1991 to $45 \%$ in 2009 due to an increase in the contribution of agriculture, manufacturing, trade, and real estate. Visayas' contribution has increased also in the same period from $12 \%$ to $19 \%$, though not as significant as Mindanao's. Meanwhile, between-region inequality has lowered its contribution from $13 \%$ in 1975 to $2 \%$ in 2009; but, this is attributable mostly to a decrease in the contribution of agriculture. In 2009, the manufacturing sector contributed most to overall interregional inequality at 35\%, which is followed by trade (27\%), agriculture (10\%), private services $(6 \%)$ and construction $(5 \%)$, which are compared to the corresponding figures of $42 \%, 16 \%, 31 \%, 2 \%$, and $5 \%$ in 1975. 


\section{Conclusions}

This paper has analyzed changes in the determinants of interregional income inequality associated with changes in the structure of industry and the geographical distribution of economic activities in the Philippines over the period from 1975-2009. This was accomplished by using the bi-dimensional decomposition method of the squared weighted coefficient of variation.

Major findings are summarized as follows. First, when the National Capital Region of Metropolitan Manila (NCR) is included, inequality within Luzon (Island Region 1) has been the dominant contributor to overall interregional income inequality. Thus, the trend pattern of overall inequality corresponds very closely to that of inequality within Luzon. In the slow growth period from 1975-1986 (the period of Marcos' authoritarian rule), overall inequality has declined, while in the high growth period from 2000-2009 (post-Asian financial crisis period), it has increased prominently. These falling and rising inequalities coincide with Luzon's inequality trends. When NCR is excluded, however, Luzon realized relatively balanced regional development, particularly after the Local Government Code was introduced in 1991.

Second, inequality within Visayas (Island Region 2) has been very low and stable, reflecting Visayas' relatively homogeneous development; thus its contribution to overall inequality has been very small at around $1-2 \%$ when NCR is included. Third, since the establishment of the Autonomous Region in Muslim Mindanao (ARMM) and Caraga in the middle of the 1990s, inequality within Mindanao (Island Region 3) has risen prominently. When NCR is excluded, it has overtaken Luzon's within-region inequality in around 2000, and its contribution to overall inequality has increased conspicuously.

Fourth, when NCR is included, the tertiary sector has raised its contribution from $46 \%$ to $75 \%$, due to an increase in the contribution of Luzon's transportation/communication, finance and private services. This offsets a decrease in the contribution of the secondary sector in Luzon, making Luzon's contribution to overall inequality almost constant at around $83-85 \%$. The manufacturing sector has lowered its contribution; but it was still the largest contributor in 2009 at $32 \%$. Meanwhile, private services, finance and transportation/communication have emerged as prominent contributors to overall inequality. Fifth, even if NCR is excluded, the tertiary sector has raised its contribution, owing mainly to an increase in the 
contribution of trade and private services. This offsets a decrease in the contribution of agriculture, though agriculture has maintained a positive and large contribution to overall inequality. Even if NCR is excluded, the contribution of manufacturing was the largest at $35 \%$ in 2009 . Within the tertiary sector, only trade has emerged as a prominent contributor to overall inequality. As described above, Mindanao's contribution has increased conspicuously when NCR is excluded. This is attributable primarily to an increase in the contribution of agriculture, manufacturing, trade, and real estate.

As indicated by a huge difference between the levels of overall interregional inequality calculated based on GRDP including and excluding NCR, one major determinant of interregional income inequality is the primacy of NCR as the center of economic activities. With strong urbanization economies under economic liberalization and globalization, NCR has grown relatively rapidly since the 1990s, with the exception of the periods of energy crisis and natural disasters of 1991-1992 and the Asian financial crisis of 1997-1998; and the difference has widened, in which the tertiary sector, particularly transportation/communication, finance, and private services, has played an increasingly important role.

The reduction of the disparity between NCR and the rest of Luzon is thus essential to decreasing Luzon's high within-region inequality and overall inequality. But this is not easy to accomplish, since services sectors have enjoyed agglomeration economies that NCR has nurtured under economic liberalization and globalization. Decentralization, which started in the early 1990s, has been one way to ameliorate the disparity, but its effects are ambiguous. Another option would be to relocate some manufacturing activities to areas outside NCR where they could enjoy localization economies. Government policies should be designed to provide an environment that is conducive to such relocation.

ARMM in Mindanao is the poorest in the Philippines and its per capita GRDP is merely $23 \%$ of the national average in 2009 , which is less than a half of the per capita GRDP of the next poorest in Mindanao, i.e., Caraga. Agriculture dominates its economy by accounting for about $60 \%$ of its total GRDP, while the GRDP share of manufacturing amounts to only 5\%. To reduce inequality within Mindanao, another major determinant of interregional inequality in the Philippines, it is thus imperative to 
raise the productivity of ARMM's agriculture and fishery and promote labor-intensive food processing manufacturing activities.

\section{References}

Akita, T. and Miyata, S. 2010. The Bi-dimensional Decomposition of Regional Inequality based on The Weighted Coefficient of Variation. Letters on Spatial Resource Science 3(3), 91-100.

Akita, T., Kurniawan, P.A. and Miyata, S. 2011. Structural Changes and Regional Incime Inequality in Indonesia: A Bi-dimensional Decomposition Analysis. Asian Economic Journal 25(1), 55-77.

Anand, S. 1983. Inequality and Poverty in Malaysia: Measurement and Decomposition. World Bank Research Publication, Oxford University Press, New York.

Balisacan, A. M. 2007. Local Growth and Poverty Reduction. In Balisacan, A. M. and Hill, H. (eds), The Dynamics of Regional Development: The Philippines in East Asia. Edward Elgar Publishing, Inc, Cheltenham, UK.

Balisacan, A. M. and Fuwa, N. 2003. Growth, Inequality and Politics Revisited: A Developing-country Case. Economics Letters 79(1), 53-58.

Balisacan, A. M. and Fuwa, N. 2004a. Going beyond Crosscountry Averages: Growth, Inequality and Poverty Reduction in the Philippines. World Development 32(11), 1891-1907.

Balisacan, A. M. and Fuwa, N. 2004b. Changes in Spatial Income Inequality in the Philippines: An Exploratory Analysis. Research Paper 2004/34, WIDER, United Nations University, .

Balisacan, A. M., Hill, H. and Piza, S. F. A. 2008. Regional Development Dynamics and Decentralization in the Philippines. ASEAN Economic Bulletin 25(3), 293-315.

Barro, R. J. and Sala-i-Martin, X. 1992. Convergence. Journal of Political Economy 100(2), 223-251.

Barro, R. J. and Sala-i-Martin, X. 1995. Economic Growth. McGraw Hill, New York.

Capuno, J. J. 2011. Incumbents and Innovations under Decentralization: An Empirical Exploration of Selected Local Governments in the Philippines. Asian Journal of Political Science 19(1), 48-73.

Capuno, J. J. 2012. Agglomeration and Sub-regional Disparities under Decentralization: Evidence of Spatial Clustering of Land Values in the Philippines. Review of Urban and Regional Development Studies 24(3) 106-120.

Clausen, A. 2010. Economic Globalization and Regional Disparities in the Philippines. Singapore Journal of Tropical Geography 31, 299-316. 
Estudillo, J. P. 1997. Income Inequality in the Philippines, 1961-91. Developing Economies 35(1), 68-95.

Fields, G. S. 2001. Distribution and Development. MIT Press, Cambridge, MA.

Hill, H., Balisacan, A. M., and Piza, S. F. A. 2007. The Philippines and Regional Development. In Balisacan, A. M. and Hill, H. (eds), The Dynamics of Regional Development: The Philippines in East Asia. Edward Elgar Publishing, Inc, Cheltenham, UK.

Manasan, R. G. 2007. Decentralization and the Financing of Regional Development. In Balisacan, A. M. and Hill, H. (eds), The Dynamics of Regional Development: The Philippines in East Asia. Edward Elgar Publishing, Inc, Cheltenham, UK.

Manasan, R.G. and Chatterjee, S. 2003. Regional Development. In Balisacan, A., and Hill, H. (eds.), The Philippine Economy: Development, Policies and Challenges. Ateneo de Manila University Press, Quezon City, Philippines.

Manasan, R. G. and Mercado, R. 1999. Regional Economic Growth and Convergence in the Philippines: 1975-1997. Discussion Paper Series 1999-13, Philippine Institute of Development Studies, Manila.

Mapa, D. S., Balisacan, A.M. and Briones, K. J. S. 2006. Robust Determinants of Income Growth in the Philippines. Philippine Journal of Development 33(1/2), $1-32$.

Mapa, D. S., Balisacan, A. M., Briones, K. J. S. and Albis, M. L. F. 2009. What Really Matters for Income Growth in the Philippines: Empirical Evidence from Provincial Data. UPSS Working Paper Series 2009-01, School of Statistics, University of the Philippines, Diliman.

Mercado, R. 2002. Regional Development in the Philippines: A Review of Experience, State of the Art and Agenda for Research and Action. Discussion Paper Series No. 2002-03, Philippine Institute of Development Studies, Manila.

NSCB (National Statistical Coordination Board). various issues. Regional Accounts of the Philippines. National Statistical Coordination Board, Manila.

NSO (National Statistics Office). various issues. Philippine Statistical Yearbook. National Statistics Office, Manila.

Shorrocks, A. and Wan, G. 2005. Spatial Decomposition of Inequality. Journal of Economic Geography 5(1), 59-81.

Tecson, G. R. 2007. Regional Response to Trade Liberalization and Economic Decentralization. In Balisacan, A. M. and Hill, H. (eds), The Dynamics of Regional Development: The Philippines in East Asia. Edward Elgar Publishing, Inc, Cheltenham, UK.

Williamson, J. G. 1965. Regional Inequality and the Process of National Development: A Description of the Patterns. Economic Development and Cultural Change 13(4), $3-45$. 


\section{Appendix: Bi-dimensional Decomposition Method of the Squared WCV}

All administrative regions in the Philippines are classified into three island regions: Luzon, Visayas and Mindanao and let $h_{i}$ be the number of regions in island region $i$ where $i=1$ for Luzon, $i=2$ for Visayas and $i=3$ for Mindanao. Suppose that $\bar{y}_{i j}=$ per capita GRDP of region $j$ in island region $i ; N_{i j}=$ population of region $j$ in island region $i ; \quad N_{i}=\sum_{j=1}^{h_{i}} N_{i j}=$ total population of island region $i ; \quad Y_{i}=\sum_{j=1}^{h_{i}} N_{i j} \bar{y}_{i j}=$ total GRDP of island region $i ; \bar{Y}_{i}=Y_{i} / N_{i}=$ per capita GRDP of island region $i ; N=\sum_{i=1}^{3} \sum_{j=1}^{h_{i}} N_{i j}=$ total population of all regions; $Y=\sum_{i=1}^{3} \sum_{j=1}^{h_{i}} N_{i j} \bar{y}_{i j}=$ total GRDP of all regions; and $\bar{Y}=Y / N=$ per capita GRDP of all regions. Then, overall inequality in per capita GRDP among regions can be measured by using the squared population-weighted coefficient of variation (the squared WCV hereafter) as follows:

$$
C V(\boldsymbol{Y})^{2}=\frac{1}{\bar{Y}^{2}} \sum_{i=1}^{3} \sum_{j=1}^{h_{i}} \frac{N_{i j}}{N}\left(\bar{y}_{i j}-\bar{Y}\right)^{2},
$$

where $\boldsymbol{Y}=\left(\boldsymbol{Y}_{1}, \boldsymbol{Y}_{2}, \boldsymbol{Y}_{3}\right)$ and $\boldsymbol{Y}_{i}=\left(\bar{y}_{i 1}, \bar{y}_{i 2}, \ldots, \bar{y}_{i h_{i}}\right)$.

The squared WCV in equation (A1) belongs to the generalized entropy class of inequality measures given by:

$$
G E_{\alpha}(\boldsymbol{Y})=\frac{1}{\alpha(\alpha-1)} \sum_{i=1}^{3} \sum_{j=1}^{h_{i}} \frac{N_{i j}}{N}\left[\left(\frac{\bar{y}_{i j}}{\bar{Y}}\right)^{\alpha}-1\right] \text { where } \alpha \neq 0,1
$$

It satisfies several desirable properties, such as anonymity, population homogeneity, income homogeneity, and the Pigue-Dalton principle of transfer and is additively decomposable, i.e., can be written as the sum of the within-region and between-region inequality components as follows (see, for example, Anand, 1983; Fields, 2001; Shorrocks and Wan, 2005): 


$$
C V(\boldsymbol{Y})^{2}=\sum_{i=1}^{3}\left(\frac{N_{i}}{N}\right)\left(\frac{\bar{Y}_{i}}{\bar{Y}}\right)^{2} C V\left(\boldsymbol{Y}_{i}\right)^{2}+C V(\overline{\boldsymbol{Y}})^{2}=C V_{W}+C V_{B} .
$$

$C V_{W}$ is the within-region inequality component, which is a weighted sum of within-region inequalities $C V\left(\boldsymbol{Y}_{i}\right)^{2}$, while $C V_{B}=C V(\overline{\boldsymbol{Y}})^{2}$ is the between-region component that measures inequality in per capita GRDP among 3 island regions, where $\overline{\boldsymbol{Y}}=\left(\bar{Y}_{1}, \bar{Y}_{2}, \bar{Y}_{3}\right)$.

Suppose next that total GRDP consists of $K$ components (i.e., GRDP from $K$ industrial sectors):

$$
\bar{y}_{i j}=\bar{y}_{i j 1}+\bar{y}_{i j 2}+\cdots+\bar{y}_{i j K} \text { and } \bar{Y}_{i}=\bar{Y}_{i 1}+\bar{Y}_{i 2}+\cdots+\bar{Y}_{i K}
$$

where $\bar{Y}_{i k}=1 / N_{i} \sum_{j=1}^{h_{i}} N_{i j} \bar{y}_{i j k}$. Then, the within-region inequality of island region $i$ by the squared WCV can be decomposed additively:

$$
C V\left(\boldsymbol{Y}_{i}\right)^{2}=\sum_{k=1}^{K} z_{i k} \operatorname{COV}\left(\boldsymbol{Y}_{i}, \boldsymbol{Y}_{i k}\right) \text {. }
$$

In equation (A4), $\operatorname{COV}\left(\boldsymbol{Y}_{i}, \boldsymbol{Y}_{i k}\right)=$ weighted coefficient of covariation between total GRDP and GRDP from industry $k$ in island region $i$, where $\boldsymbol{Y}_{i k}=\left(\bar{y}_{i l k}, \bar{y}_{i 2 k}, \ldots, \bar{y}_{i h_{i} k}\right)$, and $z_{i k}=$ GRDP share of industry $k$ in island region $i$.

On the other hand, the between-region inequality can be decomposed additively as follows:

$$
C V(\overline{\boldsymbol{Y}})^{2}=\sum_{k=1}^{K} z_{k} \operatorname{COV}\left(\overline{\boldsymbol{Y}}, \overline{\boldsymbol{Y}}_{k}\right)
$$

In equation (A5), $\operatorname{COV}\left(\overline{\boldsymbol{Y}}, \overline{\boldsymbol{Y}}_{k}\right)=$ weighted coefficient of covariation between total GDP and GDP from industry $k$ in the country, where $\overline{\boldsymbol{Y}}_{\boldsymbol{\kappa}}=\left(\bar{Y}_{1 k}, \bar{Y}_{2 k}, \ldots, \bar{Y}_{m k}\right)$, and $z_{k}=$ GDP share of industry $k$ in the country.

The bi-dimensional decomposition equation of the squared WCV can now be obtained by substituting equations (A4) and (A5) into (A3):

$$
C V(\boldsymbol{Y})^{2}=\sum_{i=1}^{3}\left(\frac{N_{i}}{N}\right)\left(\frac{\bar{Y}_{i}}{\bar{Y}}\right)^{2} \sum_{k=1}^{K} z_{i k} \operatorname{COV}\left(\boldsymbol{Y}_{i}, \boldsymbol{Y}_{i k}\right)+\sum_{k=1}^{K} z_{k} \operatorname{COV}\left(\overline{\boldsymbol{Y}}, \overline{\boldsymbol{Y}}_{k}\right)=C V_{W}+C V_{B}
$$

If equation (A6) is divided by $C V(\boldsymbol{Y})^{2}$, we have: 


$$
1=\sum_{i=1}^{3}\left(\frac{N_{i}}{N}\right)\left(\frac{\bar{Y}_{i}}{\bar{Y}}\right)^{2} \sum_{k=1}^{K} z_{i k} s_{i k}+\sum_{k=1}^{K} z_{k} \bar{s}_{k}
$$

where $s_{i k}=\frac{\operatorname{COV}\left(\boldsymbol{Y}_{i}, \boldsymbol{Y}_{i k}\right)}{C V(\boldsymbol{Y})^{2}}$ and $\bar{s}_{k}=\frac{\operatorname{COV}\left(\overline{\boldsymbol{Y}}, \overline{\boldsymbol{Y}}_{k}\right)}{C V(\boldsymbol{Y})^{2}}$. In equation (7), $\left(\frac{N_{i}}{N}\right)\left(\frac{\bar{Y}_{i}}{\bar{Y}}\right)^{2} z_{i k} s_{i k}$ is the contribution of the within-region inequality of GDP component $k$ in island region $i$ to overall inequality. On the other hand, $z_{k} \bar{s}_{k}$ is the contribution of the between-region inequality of GDP component $k$ to overall inequality.

We now define $v_{i k}=\frac{\operatorname{COV}\left(\boldsymbol{Y}_{i}, \boldsymbol{Y}_{i k}\right)}{C V\left(\boldsymbol{Y}_{i}\right)^{2}}$ and $\bar{v}_{k}=\frac{\operatorname{COV}\left(\overline{\boldsymbol{Y}}, \overline{\boldsymbol{Y}}_{k}\right)}{\operatorname{CV}(\overline{\boldsymbol{Y}})^{2}}$, which are called, respectively, the relative concentration coefficient of GRDP component $k$ for the within-region inequality of island region $i$ and for the between-region inequality among island regions. If $v_{i k}>1 \quad\left(v_{i k}<1\right)$, then industry $k$ is an inequality-increasing (inequality-decreasing) industry in island region $i$. On the other hand, if $\bar{v}_{k}>1 \quad\left(\bar{v}_{k}<1\right)$, then industry $k$ is an inequality-increasing (inequality-decreasing) industry for the between-region inequality.

When $\alpha=0$ and 1 in equation (A2), the generalize entropy class of inequality measures is expressed, respectively, as:

$$
G E_{0}(\boldsymbol{Y})=L=\sum_{i=1}^{3} \sum_{j=1}^{h_{i}} \frac{N_{i j}}{N} \ln \left(\frac{\bar{Y}}{\bar{y}_{i j}}\right) \text { and } G E_{1}(\boldsymbol{Y})=T=\sum_{i=1}^{3} \sum_{j=1}^{h_{i}} \frac{N_{i j}}{N} \frac{\bar{y}_{i j}}{\bar{Y}} \ln \left(\frac{\bar{y}_{i j}}{\bar{Y}}\right) \text {. }
$$

$G E_{0}(\boldsymbol{Y})$ is usually called the Theil $L$ (or the mean logarithmic deviation), while $G E_{1}(\boldsymbol{Y})$ is the Theil $T$. These two measures are also additively decomposable by population sub-groups as follows, though they are not additively decomposable by GDP components.

$$
\begin{aligned}
& L=\sum_{i=1}^{3} \frac{N_{i}}{N} L_{i}+\sum_{i=1}^{3} \frac{N_{i}}{N} \ln \left(\frac{\bar{Y}}{\bar{Y}_{i}}\right)=L_{W}+L_{B} \text { and } \\
& T=\sum_{i=1}^{3} \frac{N_{i}}{N} \frac{\bar{Y}_{i}}{\bar{Y}} T_{i}+\sum_{i=1}^{3} \frac{N_{i}}{N} \frac{\bar{Y}_{i}}{\bar{Y}} \ln \left(\frac{\bar{Y}_{i}}{\bar{Y}}\right)=T_{W}+T_{B},
\end{aligned}
$$

where $L_{i}$ and $T_{i}$ are the within-region inequalities of island region $i$ by the Theil $L$ and $T$, respectively. 
Table 1

Share of Each Industry to National GDP (in \%)

\begin{tabular}{|c|c|c|c|c|c|c|c|c|c|c|c|c|c|c|}
\hline & \multicolumn{2}{|c|}{ Primary } & \multirow[b]{2}{*}{ Subtotal } & \multicolumn{3}{|c|}{ Secondary } & \multirow[b]{2}{*}{ Subtotal } & \multicolumn{6}{|c|}{ Tertiary } & \multirow[b]{2}{*}{ Subtotal } \\
\hline & 1 & 2 & & 3 & 4 & 5 & & 6 & 7 & 8 & 9 & 10 & 11 & \\
\hline 1975 & 24.7 & 1.3 & 26.0 & 28.3 & 7.0 & 1.8 & 37.1 & 4.8 & 12.5 & 3.3 & 6.5 & 5.2 & 4.7 & 37.0 \\
\hline 1986 & 24.6 & 2.1 & 26.7 & 24.8 & 4.8 & 3.0 & 32.6 & 5.6 & 14.7 & 3.1 & 5.6 & 6.8 & 4.9 & 40.7 \\
\hline 1991 & 22.7 & 1.5 & 24.2 & 25.6 & 4.9 & 2.7 & 33.2 & 5.8 & 15.1 & 4.1 & 5.6 & 6.9 & 5.2 & 42.6 \\
\hline 2000 & 20.0 & 1.1 & 21.1 & 24.8 & 5.1 & 3.4 & 33.3 & 7.1 & 16.0 & 4.9 & 5.1 & 7.4 & 5.1 & 45.6 \\
\hline 2009 & 18.1 & 2.0 & 20.1 & 22.0 & 5.0 & 3.1 & 30.1 & 8.8 & 16.7 & 6.2 & 4.7 & 9.1 & 4.3 & 49.8 \\
\hline
\end{tabular}

Source: Authors' calculation based on Regional Accounts of the Philippines (NSCB, various issues).

Notes: The numbers on the top row represent: (1) agriculture, fisheries and forestry; (2) mining and quarrying; (3) manufacturing; (4) construction; (5) electricity, gas and water; (6) transportation and communication; (7) trade; (8) finance; (9) real estate; (10) private services; and (11) government services. 
Table 2

\section{Regional Structure and Growth}

(in \%)

\begin{tabular}{|c|c|c|c|c|c|c|c|c|c|c|}
\hline \multirow[b]{3}{*}{ Population } & \multicolumn{5}{|c|}{ Share } & \multicolumn{5}{|c|}{ Growth } \\
\hline & 1975 & 1986 & 1991 & 2000 & 2009 & $1975-86$ & $1986-91$ & 1991-00 & 2000-09 & 1975-09 \\
\hline & & & & & & & & & & \\
\hline Luzon & 54.2 & 54.5 & 54.9 & 56.0 & 56.0 & 2.6 & 2.6 & 2.4 & 2.0 & 2.4 \\
\hline NCR & 11.8 & 12.8 & 13.0 & 13.0 & 12.4 & 3.3 & 2.8 & 2.2 & 1.5 & 2.4 \\
\hline CAR & & & 1.9 & 1.8 & 1.8 & & & 1.7 & 2.1 & 1.9 \\
\hline Ilocos & 7.8 & 7.0 & 5.7 & 5.5 & 5.5 & 1.6 & -1.7 & 1.8 & 2.1 & 1.3 \\
\hline Cagayan Valley & 4.6 & 4.6 & 4.0 & 3.7 & 3.6 & 2.6 & -0.3 & 1.2 & 1.8 & 1.6 \\
\hline Central Luzon & 10.0 & 10.0 & 10.0 & 10.5 & 10.8 & 2.5 & 2.5 & 2.8 & 2.3 & 2.5 \\
\hline Southern Tagalog & 12.4 & 13.1 & 13.2 & 15.5 & 15.8 & 3.0 & 2.7 & 4.0 & 2.3 & 3.0 \\
\hline Bicol & 7.6 & 7.0 & 7.1 & 6.1 & 6.1 & 1.8 & 2.8 & 0.5 & 2.0 & 1.7 \\
\hline Visayas & 24.1 & 22.6 & 22.1 & 20.3 & 20.3 & 1.9 & 2.1 & 1.3 & 2.0 & 1.8 \\
\hline Western Visayas & 9.9 & 9.2 & 9.2 & 8.1 & 8.1 & 1.9 & 2.4 & 0.8 & 2.0 & 1.7 \\
\hline Central Visayas & 8.1 & 7.7 & 7.5 & 7.5 & 7.5 & 2.1 & 1.9 & 2.2 & 2.1 & 2.1 \\
\hline Eastern Visayas & 6.2 & 5.7 & 5.4 & 4.7 & 4.7 & 1.7 & 1.7 & 0.6 & 2.1 & 1.5 \\
\hline Mindanao & 21.7 & 23.0 & 22.9 & 23.7 & 23.8 & 3.0 & 2.4 & 2.6 & 2.1 & 2.6 \\
\hline Western Mindanao & 4.9 & 5.2 & 5.2 & 4.0 & 3.7 & 3.1 & 2.5 & -0.6 & 1.1 & 1.5 \\
\hline Northern Mindanao & 5.5 & 5.9 & 5.9 & 3.6 & 4.6 & 3.2 & 2.4 & -3.3 & 4.8 & 1.8 \\
\hline Southern Mindanao & 6.5 & 7.3 & 7.1 & 6.8 & 4.7 & 3.6 & 1.8 & 1.8 & -2.2 & 1.3 \\
\hline Central Mindanao & 4.9 & 4.6 & 4.8 & 3.4 & 4.3 & 1.8 & 3.5 & -1.6 & 4.7 & 1.9 \\
\hline ARMM & & & & 3.2 & 3.8 & & & & 4.0 & 4.0 \\
\hline Caraga & & & & 2.7 & 2.7 & & & & 1.9 & 1.9 \\
\hline Total & 100.0 & 100.0 & 100.0 & 100.0 & 100.0 & 2.5 & 2.5 & 2.2 & 2.0 & 2.3 \\
\hline \multicolumn{11}{|l|}{ GDP (in 1985 prices) } \\
\hline Luzon & 62.5 & 63.0 & 65.5 & 65.7 & 64.9 & 2.5 & 4.6 & 3.2 & 4.4 & 3.5 \\
\hline NCR & 29.0 & 28.6 & 30.8 & 31.1 & 32.5 & 2.3 & 5.3 & 3.3 & 5.0 & 3.7 \\
\hline CAR & & & 2.0 & 2.3 & 2.2 & & & 5.1 & 3.9 & 4.5 \\
\hline Ilocos & 4.0 & 4.6 & 3.0 & 3.2 & 2.8 & 3.6 & -4.4 & 3.8 & 3.3 & 2.4 \\
\hline Cagayan Valley & 2.9 & 2.6 & 2.1 & 2.3 & 2.0 & 1.7 & -1.3 & 4.3 & 2.9 & 2.3 \\
\hline Central Luzon & 9.1 & 9.3 & 9.3 & 8.9 & 8.1 & 2.6 & 3.8 & 2.8 & 3.5 & 3.0 \\
\hline Southern Tagalog & 14.6 & 14.6 & 15.3 & 15.2 & 14.3 & 2.4 & 4.8 & 3.1 & 3.8 & 3.3 \\
\hline Bicol & 3.0 & 3.3 & 3.0 & 2.7 & 3.0 & 3.2 & 2.1 & 2.0 & 5.6 & 3.3 \\
\hline Visayas & 16.5 & 16.5 & 16.0 & 16.2 & 16.9 & 2.3 & 3.3 & 3.3 & 4.9 & 3.4 \\
\hline Western Visayas & 7.7 & 7.4 & 7.0 & 7.0 & 7.6 & 1.9 & 2.9 & 3.2 & 5.4 & 3.3 \\
\hline Central Visayas & 6.1 & 6.4 & 6.6 & 6.8 & 7.1 & 2.7 & 4.4 & 3.6 & 5.0 & 3.8 \\
\hline Eastern Visayas & 2.6 & 2.7 & 2.4 & 2.4 & 2.1 & 2.6 & 1.6 & 3.1 & 3.2 & 2.7 \\
\hline Mindanao & 20.9 & 20.5 & 18.5 & 18.1 & 18.2 & 2.2 & 1.8 & 3.0 & 4.6 & 3.0 \\
\hline Western Mindanao & 3.2 & 3.2 & 2.9 & 2.8 & 2.7 & 2.6 & 1.6 & 2.9 & 3.9 & 2.9 \\
\hline Northern Mindanao & 5.6 & 5.6 & 5.2 & 3.8 & 5.1 & 2.4 & 2.2 & -0.2 & 7.7 & 3.1 \\
\hline Southern Mindanao & 8.3 & 7.7 & 7.0 & 6.3 & 4.7 & 1.7 & 2.0 & 2.0 & 1.2 & 1.7 \\
\hline Central Mindanao & 3.8 & 4.0 & 3.4 & 2.7 & 3.5 & 2.7 & 0.7 & 0.6 & 7.5 & 3.1 \\
\hline ARMM & & & & 1.0 & 0.9 & & & & 3.3 & 3.3 \\
\hline Caraga & & & & 1.5 & 1.3 & & & & 3.1 & 3.1 \\
\hline Total & 100.0 & 100.0 & 100.0 & 100.0 & 100.0 & 2.4 & 3.8 & 3.2 & 4.5 & 3.4 \\
\hline
\end{tabular}

Source: Authors' calculation based on Regional Accounts of the Philippines (NSCB, various issues); and Philippine Statistical Yearbook (NSO, various issues). 
Table 3

Per Capita GDP Growth

(in \%)

\begin{tabular}{lrrrrrrrrrrr}
\hline & \multicolumn{1}{c}{ Per Capita GDP (Philippines = 100) } & \multicolumn{5}{c}{ Growth } \\
\cline { 2 - 13 } & 1975 & 1986 & 1991 & 2000 & 2009 & $1975-86$ & $1986-91$ & $1991-00$ & $2000-09$ & $1975-09$ \\
\hline Luzon & 115 & 116 & 119 & 117 & 116 & -0.1 & 2.0 & 0.8 & 2.4 & 1.1 \\
NCR & 246 & 224 & 237 & 239 & 263 & -1.0 & 2.5 & 1.1 & 3.5 & 1.3 \\
CAR & & & 105 & 131 & 122 & & & 3.4 & 1.7 & 2.6 \\
Ilocos & 52 & 65 & 53 & 58 & 52 & 2.0 & -2.8 & 2.0 & 1.2 & 1.1 \\
Cagayan Valley & 62 & 57 & 51 & 62 & 55 & -0.9 & -1.0 & 3.0 & 1.2 & 0.7 \\
Central Luzon & 91 & 93 & 93 & 85 & 75 & 0.1 & 1.3 & 0.0 & 1.1 & 0.5 \\
Southern Tagalog & 118 & 112 & 116 & 98 & 90 & -0.6 & 2.1 & -0.9 & 1.5 & 0.3 \\
Bicol & 40 & 47 & 43 & 44 & 49 & 1.4 & -0.7 & 1.5 & 3.6 & 1.7 \\
\hline Visayas & 69 & 73 & 72 & 80 & 83 & 0.4 & 1.2 & 2.1 & 2.9 \\
Western Visayas & 79 & 80 & 76 & 87 & 95 & 0.0 & 0.5 & 2.3 & 3.5 & 1.6 \\
Central Visayas & 76 & 83 & 88 & 91 & 95 & 0.6 & 2.5 & 1.4 & 2.9 & 1.6 \\
Eastern Visayas & 43 & 48 & 45 & 51 & 45 & 0.9 & -0.1 & 2.4 & 1.1 & 1.2 \\
\hline Mindanao & 96 & 89 & 81 & 76 & 77 & -0.8 & -0.7 & 0.4 & 2.5 \\
Western Mindanao & 65 & 62 & 56 & 70 & 72 & -0.5 & -0.8 & 3.5 & 2.8 & 0.4 \\
Northern Mindanao & 102 & 95 & 88 & 106 & 111 & -0.8 & -0.2 & 3.1 & 2.9 & 1.4 \\
Southern Mindanao & 129 & 105 & 99 & 93 & 101 & -2.0 & 0.2 & 0.2 & 3.4 & 0.4 \\
Central Mindanao & 78 & 87 & 71 & 79 & 82 & 0.9 & -2.7 & 2.1 & 2.8 & 1.2 \\
ARMM & & & & 30 & 23 & & & & -0.6 & -0.6 \\
Caraga & & & & 55 & 49 & & & & 1.2 \\
\hline Total & 100 & 100 & 100 & 100 & 100 & -0.1 & 1.4 & 1.0 & 2.5 \\
\hline
\end{tabular}

Source: Authors' calculation based on Regional Accounts of the Philippines (NSCB, various issues); and Philippine Statistical Yearbook (NSO, various issues). 
Table 4

Decomposition of Interregional Inequality by Regional Groups, including NCR

\begin{tabular}{|c|c|c|c|c|c|c|c|c|c|c|}
\hline & \multicolumn{5}{|c|}{ Inequality } & \multicolumn{5}{|c|}{ Contribution (\%) } \\
\hline & 1975 & 1986 & 1991 & 2000 & 2009 & 1975 & 1986 & 1991 & 2000 & 2009 \\
\hline \multicolumn{11}{|c|}{ Theil L } \\
\hline WR1 & 0.193 & 0.142 & 0.174 & 0.158 & 0.193 & 74.6 & 74.1 & 72.3 & 68.7 & 67.0 \\
\hline WR2 & 0.030 & 0.024 & 0.032 & 0.025 & 0.043 & 5.2 & 5.1 & 5.3 & 4.0 & 5.4 \\
\hline WR3 & 0.034 & 0.018 & 0.023 & 0.064 & 0.114 & 5.2 & 3.9 & 4.0 & 11.8 & 16.8 \\
\hline WR & 0.119 & 0.087 & 0.108 & 0.109 & 0.144 & 85.0 & 83.1 & 81.6 & 84.5 & 89.2 \\
\hline BR & 0.021 & 0.018 & 0.024 & 0.020 & 0.018 & 15.0 & 16.9 & 18.4 & 15.5 & 10.8 \\
\hline Total & 0.140 & 0.105 & 0.132 & 0.129 & 0.161 & 100.0 & 100.0 & 100.0 & 100.0 & 100.0 \\
\hline \multicolumn{11}{|c|}{ Theil T } \\
\hline WR1 & 0.188 & 0.141 & 0.166 & 0.161 & 0.205 & 79.2 & 78.8 & 77.2 & 76.2 & 77.2 \\
\hline WR2 & 0.027 & 0.021 & 0.029 & 0.022 & 0.037 & 3.0 & 3.1 & 3.3 & 2.6 & 3.6 \\
\hline WR3 & 0.033 & 0.017 & 0.022 & 0.054 & 0.089 & 4.6 & 3.0 & 2.9 & 7.1 & 9.4 \\
\hline WR & 0.129 & 0.096 & 0.118 & 0.119 & 0.155 & 86.8 & 85.0 & 83.4 & 86.0 & 90.2 \\
\hline BR & 0.020 & 0.017 & 0.023 & 0.019 & 0.017 & 13.2 & 15.0 & 16.6 & 14.0 & 9.8 \\
\hline Total & 0.149 & 0.113 & 0.141 & 0.138 & 0.172 & 100.0 & 100.0 & 100.0 & 100.0 & 100.0 \\
\hline \multicolumn{11}{|c|}{$\begin{array}{l}\text { Squared } \\
\mathrm{WCV}\end{array}$} \\
\hline WR1 & 0.408 & 0.304 & 0.351 & 0.356 & 0.477 & 84.1 & 83.7 & 82.5 & 82.9 & 85.0 \\
\hline WR2 & 0.049 & 0.039 & 0.053 & 0.041 & 0.064 & 1.6 & 1.8 & 1.8 & 1.6 & 2.1 \\
\hline WR3 & 0.066 & 0.032 & 0.043 & 0.096 & 0.153 & 3.8 & 2.2 & 1.9 & 4.0 & 5.0 \\
\hline WR & 0.314 & 0.232 & 0.286 & 0.292 & 0.389 & 89.5 & 87.6 & 86.3 & 88.5 & 92.2 \\
\hline BR & 0.037 & 0.033 & 0.046 & 0.038 & 0.033 & 10.5 & 12.4 & 13.8 & 11.5 & 7.8 \\
\hline Total & 0.350 & 0.265 & 0.332 & 0.330 & 0.423 & 100.0 & 100.0 & 100.0 & 100.0 & 100.0 \\
\hline
\end{tabular}

Source: Authors' calculation based on Regional Accounts of the Philippines (NSCB, various issues); and Philippine Statistical Yearbook (NSO, various issues).

Note: WR stands for within-region inequalities, while BR stands for between-region inequality. 
Table 5

Decomposition of Interregional Inequality by Regional Groups, excluding NCR

\begin{tabular}{|c|c|c|c|c|c|c|c|c|c|c|}
\hline & \multicolumn{5}{|c|}{ Inequality } & \multicolumn{5}{|c|}{ Contribution (\%) } \\
\hline & 1975 & 1986 & 1991 & 2000 & 2009 & 1975 & 1986 & 1991 & 2000 & 2009 \\
\hline \multicolumn{11}{|c|}{ Theil L } \\
\hline WR1 & 0.080 & 0.051 & 0.075 & 0.044 & 0.035 & 61.5 & 64.1 & 69.8 & 47.8 & 29.2 \\
\hline WR2 & 0.030 & 0.024 & 0.032 & 0.025 & 0.043 & 13.3 & 16.2 & 15.7 & 13.0 & 16.9 \\
\hline WR3 & 0.034 & 0.018 & 0.023 & 0.064 & 0.114 & 13.3 & 12.5 & 11.8 & 38.7 & 52.1 \\
\hline WR & 0.055 & 0.035 & 0.050 & 0.045 & 0.058 & 88.0 & 92.8 & 97.2 & 99.5 & 98.2 \\
\hline BR & 0.007 & 0.003 & 0.001 & 0.000 & 0.001 & 12.0 & 7.2 & 2.8 & 0.5 & 1.8 \\
\hline Total & 0.063 & 0.038 & 0.052 & 0.045 & 0.059 & 100.0 & 100.0 & 100.0 & 100.0 & 100.0 \\
\hline \multicolumn{11}{|c|}{ Theil T } \\
\hline WR1 & 0.075 & 0.048 & 0.068 & 0.041 & 0.034 & 59.9 & 64.9 & 71.1 & 50.8 & 32.1 \\
\hline WR2 & 0.027 & 0.021 & 0.029 & 0.022 & 0.037 & 10.7 & 13.9 & 13.8 & 13.2 & 18.3 \\
\hline WR3 & 0.033 & 0.017 & 0.022 & 0.054 & 0.089 & 16.5 & 13.6 & 12.2 & 35.3 & 47.5 \\
\hline WR & 0.051 & 0.033 & 0.047 & 0.040 & 0.049 & 87.1 & 92.4 & 97.0 & 99.4 & 97.9 \\
\hline BR & 0.008 & 0.003 & 0.001 & 0.000 & 0.001 & 12.8 & 7.6 & 3.0 & 0.6 & 2.1 \\
\hline Total & 0.059 & 0.035 & 0.048 & 0.040 & 0.050 & 100.0 & 100.0 & 100.0 & 100.0 & 100.0 \\
\hline \multicolumn{11}{|c|}{$\begin{array}{l}\text { Squared } \\
\mathrm{WCV}\end{array}$} \\
\hline WR1 & 0.145 & 0.092 & 0.130 & 0.078 & 0.067 & 58.3 & 65.8 & 72.6 & 53.5 & 34.0 \\
\hline WR2 & 0.049 & 0.039 & 0.053 & 0.041 & 0.064 & 8.4 & 11.8 & 11.9 & 13.1 & 19.0 \\
\hline WR3 & 0.066 & 0.032 & 0.043 & 0.096 & 0.153 & 20.0 & 14.6 & 12.4 & 32.8 & 44.6 \\
\hline WR & 0.100 & 0.063 & 0.090 & 0.074 & 0.090 & 86.7 & 92.2 & 97.0 & 99.4 & 97.6 \\
\hline BR & 0.015 & 0.005 & 0.003 & 0.001 & 0.002 & 13.3 & 7.9 & 3.0 & 0.6 & 2.4 \\
\hline Total & 0.116 & 0.068 & 0.093 & 0.074 & 0.092 & 100.0 & 100.0 & 100.0 & 100.0 & 100.0 \\
\hline
\end{tabular}

Source: Authors' calculation based on Regional Accounts of the Philippines (NSCB, various issues); and Philippine Statistical Yearbook (NSO, various issues).

Note: WR stands for within-region inequalities, while BR stands for between-region inequality. 
Table 6

Bidimensional Decomposition by Regional Groups and GRDP Components, including NCR (in \%)

\begin{tabular}{|c|c|c|c|c|c|c|c|c|c|c|c|c|c|c|c|}
\hline & \multicolumn{2}{|c|}{ Primary } & \multirow[b]{2}{*}{ Subtotal } & \multicolumn{3}{|c|}{ Secondary } & \multirow[b]{2}{*}{ Subtotal } & \multicolumn{6}{|c|}{ Tertiary } & \multirow[b]{2}{*}{ Subtotal } & \multirow[b]{2}{*}{ Total } \\
\hline & 1 & 2 & & 3 & 4 & 5 & & 6 & 7 & 8 & 9 & 10 & 11 & & \\
\hline 1975 & & & & & & & & & & & & & & & \\
\hline WR1 & -9.1 & -0.9 & -10.0 & 43.2 & 8.5 & 2.0 & 53.8 & 6.5 & 8.5 & 7.0 & 0.2 & 9.7 & $8.5 \%$ & 40.3 & 84.1 \\
\hline WR2 & 0.2 & 0.1 & 0.3 & 0.6 & -0.1 & 0.0 & 0.5 & 0.1 & 0.6 & 0.1 & 0.0 & 0.1 & $0.0 \%$ & 0.8 & 1.6 \\
\hline WR3 & 1.7 & 0.0 & 1.7 & 0.8 & 0.2 & 0.0 & 1.0 & 0.0 & 0.9 & 0.1 & 0.1 & 0.1 & $0.0 \%$ & 1.1 & 3.8 \\
\hline BR & -0.8 & -0.1 & -0.9 & 5.5 & 1.4 & 0.6 & 7.5 & 0.8 & 0.0 & 0.9 & 0.0 & 1.1 & $1.1 \%$ & 3.9 & 10.5 \\
\hline Total & -8.0 & -0.9 & -8.9 & 50.1 & 10.1 & 2.6 & 62.8 & 7.3 & 10.0 & 8.0 & 0.3 & 11.0 & $9.5 \%$ & 46.1 & 100.0 \\
\hline \multicolumn{16}{|l|}{1986} \\
\hline WR1 & -11.9 & -1.8 & -13.6 & 37.9 & 5.6 & 1.3 & 44.7 & 9.5 & 12.1 & 8.5 & 0.8 & 13.2 & $8.5 \%$ & 52.6 & 83.7 \\
\hline WR2 & 0.1 & 0.2 & 0.2 & 0.3 & 0.0 & 0.0 & 0.4 & 0.1 & 0.8 & 0.1 & 0.0 & 0.2 & $0.0 \%$ & 1.2 & 1.8 \\
\hline WR3 & 0.7 & 0.1 & 0.8 & 0.7 & 0.0 & 0.0 & 0.7 & 0.0 & 0.7 & 0.0 & 0.0 & 0.1 & $0.0 \%$ & 0.7 & 2.2 \\
\hline BR & -2.1 & 0.0 & -2.1 & 5.7 & 1.4 & 0.9 & 8.0 & 1.5 & 0.6 & 1.3 & 0.1 & 1.8 & $1.3 \%$ & 6.5 & 12.4 \\
\hline Total & -13.3 & -1.5 & -14.7 & 44.6 & 7.0 & 2.2 & 53.8 & 11.1 & 14.2 & 9.8 & 0.9 & 15.2 & $9.7 \%$ & 61.0 & 100.0 \\
\hline \multicolumn{16}{|l|}{1991} \\
\hline WR1 & -9.9 & -0.8 & -10.7 & 33.9 & 4.7 & 1.9 & 40.5 & 9.3 & 11.1 & 10.4 & 1.3 & 11.7 & $8.9 \%$ & 52.7 & 82.5 \\
\hline WR2 & 0.1 & 0.1 & 0.2 & 0.3 & 0.1 & 0.0 & 0.4 & 0.1 & 0.9 & 0.1 & 0.0 & 0.2 & $0.0 \%$ & 1.3 & 1.8 \\
\hline WR3 & 0.6 & 0.1 & 0.7 & 0.5 & 0.0 & 0.0 & 0.5 & 0.0 & 0.7 & 0.0 & 0.0 & 0.1 & $0.0 \%$ & 0.8 & 1.9 \\
\hline BR & -2.2 & -0.1 & -2.3 & 6.5 & 1.6 & 0.9 & 8.9 & 1.6 & 0.3 & 1.8 & 0.2 & 1.9 & $1.5 \%$ & 7.1 & 13.8 \\
\hline Total & -11.5 & -0.6 & -12.1 & 41.1 & 6.4 & 2.8 & 50.3 & 11.0 & 13.0 & 12.2 & 1.5 & 13.8 & $10.3 \%$ & 61.9 & 100.0 \\
\hline \multicolumn{16}{|l|}{2000} \\
\hline WR1 & -10.4 & -0.2 & -10.6 & 30.6 & 3.0 & 2.0 & 35.6 & 12.4 & 11.0 & 13.2 & 1.4 & 13.0 & $6.9 \%$ & 57.9 & 82.9 \\
\hline WR2 & 0.1 & 0.1 & 0.2 & 0.2 & 0.0 & 0.0 & 0.2 & 0.2 & 0.9 & 0.1 & 0.0 & 0.2 & $0.0 \%$ & 1.3 & 1.6 \\
\hline WR3 & 0.8 & 0.1 & 0.8 & 1.2 & 0.1 & 0.0 & 1.3 & 0.2 & 1.2 & 0.1 & 0.3 & 0.2 & $0.0 \%$ & 1.9 & 4.0 \\
\hline BR & -2.2 & -0.2 & -2.4 & 5.5 & 0.4 & 0.9 & 6.8 & 1.9 & 0.3 & 2.0 & 0.2 & 1.9 & $0.9 \%$ & 7.1 & 11.5 \\
\hline Total & -11.7 & -0.3 & -12.0 & 37.5 & 3.5 & 2.9 & 44.0 & 14.6 & 13.3 & 15.3 & 1.9 & 15.2 & $7.8 \%$ & 68.1 & 100.0 \\
\hline \multicolumn{16}{|l|}{2009} \\
\hline WR1 & -8.3 & -0.9 & -9.2 & 27.0 & 0.4 & 1.7 & 29.1 & 15.3 & 10.3 & 15.7 & 1.6 & 16.8 & $5.2 \%$ & 65.1 & 85.0 \\
\hline WR2 & 0.1 & 0.1 & 0.2 & 0.4 & 0.1 & 0.0 & 0.5 & 0.2 & 1.0 & 0.1 & 0.1 & 0.2 & $0.0 \%$ & 1.5 & 2.1 \\
\hline WR3 & 1.1 & 0.0 & 1.1 & 1.4 & 0.4 & 0.0 & 1.9 & 0.2 & 1.3 & 0.1 & 0.3 & 0.2 & $0.0 \%$ & 2.1 & 5.0 \\
\hline BR & -1.7 & 0.0 & -1.7 & 2.8 & 0.0 & 0.6 & 3.4 & 1.7 & 0.1 & 1.8 & 0.1 & 1.8 & $0.5 \%$ & 6.1 & 7.8 \\
\hline Total & -8.8 & -0.8 & -9.6 & 31.6 & 0.9 & 2.4 & 34.8 & 17.4 & 12.7 & 17.7 & 2.1 & 19.1 & $5.7 \%$ & 74.7 & 100.0 \\
\hline
\end{tabular}

Source: Authors' calculation based on Regional Accounts of the Philippines (NSCB, various issues); and Philippine Statistical Yearbook (NSO, various issues).

Notes: 1. The numbers on the top row represent: (1) agriculture, fisheries and forestry, (2) mining \& quarrying, (3) manufacturing, (4) construction, (5) electricity, gas and water supply, (6) transportation, storage and communication, (7) trade, (8) finance, (9) real estate, (10) private services; and (11) government services.

2. WR stands for within-region inequalities, while BR stands for between-region inequality. 
Table 7

Bidimensional Decomposition by Regional Groups and GRDP Components, excluding NCR (in \%)

\begin{tabular}{|c|c|c|c|c|c|c|c|c|c|c|c|c|c|c|c|}
\hline & \multicolumn{2}{|c|}{ Primary } & \multirow[b]{2}{*}{ Subtotal } & \multicolumn{3}{|c|}{ Secondary } & \multirow[b]{2}{*}{ Subtotal } & \multicolumn{6}{|c|}{ Tertiary } & \multirow[b]{2}{*}{ Subtotal } & \multirow[b]{2}{*}{ Total } \\
\hline & 1 & $\overline{2}$ & & 3 & $\overline{4}$ & 5 & & $\overline{6}$ & 7 & 8 & 9 & 10 & 11 & & \\
\hline \multicolumn{16}{|l|}{1975} \\
\hline WR1 & 8.2 & -0.6 & 7.6 & 33.1 & 3.7 & 1.5 & 38.3 & 1.9 & 7.7 & 1.9 & 0.0 & 0.7 & 0.2 & 12.4 & 58.3 \\
\hline WR2 & 1.1 & 0.3 & 1.4 & 3.2 & -0.4 & 0.1 & 2.9 & 0.4 & 3.2 & 0.3 & -0.1 & 0.5 & 0.0 & 4.2 & 8.4 \\
\hline WR3 & 9.1 & 0.0 & 9.1 & 4.0 & 1.1 & -0.1 & 5.0 & 0.2 & 4.6 & 0.3 & 0.3 & 0.5 & -0.1 & 5.9 & 20.0 \\
\hline BR & 12.1 & -0.8 & 11.3 & 1.9 & 0.2 & -0.1 & 2.0 & 0.0 & 0.1 & -0.2 & 0.4 & -0.3 & 0.0 & 0.0 & 13.3 \\
\hline Total & 30.5 & -1.2 & 29.4 & 42.2 & 4.7 & 1.3 & 48.2 & 2.5 & 15.5 & 2.3 & 0.6 & 1.5 & 0.1 & 22.4 & 100.0 \\
\hline \multicolumn{16}{|l|}{1986} \\
\hline WR1 & 10.6 & -1.7 & 8.8 & 33.9 & 1.8 & 3.0 & 38.7 & 2.9 & 13.4 & 1.6 & -0.6 & 1.7 & -0.7 & 18.2 & 65.8 \\
\hline WR2 & 0.3 & 1.0 & 1.3 & 2.3 & 0.3 & 0.1 & 2.7 & 0.7 & 5.6 & 0.3 & -0.1 & 1.4 & -0.2 & 7.8 & 11.8 \\
\hline WR3 & 4.5 & 1.0 & 5.4 & 4.4 & -0.1 & 0.1 & 4.5 & -0.1 & 4.4 & 0.1 & 0.0 & 0.4 & -0.2 & 4.7 & 14.6 \\
\hline BR & 9.0 & -0.5 & 8.5 & 0.7 & 0.3 & 0.3 & 1.4 & -0.1 & -0.8 & -0.2 & 0.0 & -0.8 & 0.0 & -2.0 & 7.9 \\
\hline Total & 24.3 & -0.2 & 24.1 & 41.3 & 2.4 & 3.5 & 47.2 & 3.4 & 22.6 & 1.8 & -0.7 & 2.7 & -1.1 & 28.7 & 100.0 \\
\hline \multicolumn{16}{|l|}{1991} \\
\hline WR1 & 10.5 & 0.6 & 11.1 & 38.0 & 1.4 & 4.3 & 43.7 & 2.4 & 11.3 & 1.7 & 0.5 & 2.4 & -0.3 & 17.9 & 72.6 \\
\hline WR2 & 0.4 & 0.7 & 1.1 & 1.8 & 0.3 & 0.2 & 2.3 & 0.9 & 6.0 & 0.4 & 0.2 & 1.2 & -0.2 & 8.5 & 11.9 \\
\hline WR3 & 3.6 & 0.7 & 4.3 & 3.1 & 0.2 & -0.1 & 3.2 & 0.0 & 4.3 & 0.1 & 0.1 & 0.5 & -0.2 & 4.9 & 12.4 \\
\hline BR & 2.2 & 0.0 & 2.1 & 1.6 & 0.7 & 0.6 & 2.9 & 0.0 & -1.6 & -0.1 & -0.1 & -0.3 & 0.0 & -2.0 & 3.0 \\
\hline Total & 16.7 & 1.9 & 18.6 & 44.5 & 2.6 & 5.0 & 52.1 & 3.3 & 20.1 & 2.1 & 0.8 & 3.8 & -0.6 & 29.3 & 100.0 \\
\hline \multicolumn{16}{|l|}{2000} \\
\hline WR1 & 1.1 & 2.4 & 3.5 & 32.7 & 2.5 & 3.3 & 38.4 & 1.4 & 7.2 & 1.3 & -0.1 & 2.1 & -0.3 & 11.6 & 53.5 \\
\hline WR2 & 0.8 & 0.5 & 1.3 & 1.7 & -0.3 & 0.2 & 1.6 & 1.2 & 7.1 & 0.5 & 0.2 & 1.4 & -0.3 & 10.1 & 13.1 \\
\hline WR3 & 6.2 & 0.6 & 6.7 & 9.6 & 1.0 & 0.1 & 10.8 & 1.4 & 9.9 & 0.4 & 2.1 & 1.3 & 0.1 & 15.3 & 32.8 \\
\hline BR & -1.2 & 0.0 & -1.3 & 0.9 & 0.0 & 0.3 & 1.2 & 0.2 & 0.0 & 0.2 & 0.1 & 0.3 & 0.0 & 0.7 & 0.6 \\
\hline Total & 6.9 & 3.5 & 10.3 & 44.9 & 3.3 & 3.9 & 52.0 & 4.2 & 24.3 & 2.4 & 2.2 & 5.1 & -0.4 & 37.7 & 100.0 \\
\hline \multicolumn{16}{|l|}{2009} \\
\hline WR1 & 0.4 & 2.1 & 2.5 & 19.0 & 0.8 & 2.7 & 22.4 & 0.9 & 5.0 & 1.3 & 0.1 & 2.0 & -0.2 & 9.1 & 34.0 \\
\hline WR2 & 0.4 & 1.0 & 1.5 & 3.3 & 0.8 & 0.2 & 4.3 & 1.6 & 8.7 & 0.8 & 0.5 & 1.9 & -0.2 & 13.3 & 19.0 \\
\hline WR3 & 9.8 & -0.1 & 9.7 & 12.6 & 3.6 & 0.4 & 16.6 & 2.0 & 11.2 & 0.6 & 2.7 & 1.9 & 0.0 & 18.4 & 44.6 \\
\hline BR & -1.1 & -0.1 & -1.2 & 0.0 & 0.0 & -0.4 & -0.4 & 0.4 & 2.6 & 0.1 & 0.3 & 0.6 & 0.0 & 3.9 & 2.4 \\
\hline Total & 9.5 & 2.9 & 12.4 & 34.9 & 5.2 & 2.8 & 42.9 & 4.9 & 27.4 & 2.8 & 3.5 & 6.4 & -0.4 & 44.7 & 100.0 \\
\hline
\end{tabular}

Source: Authors' calculation based on Regional Accounts of the Philippines (NSCB, various issues); and Philippine Statistical Yearbook (NSO, various issues).

Notes: 1. The numbers on the top row represent: (1) agriculture, fisheries and forestry, (2) mining \& quarrying, (3) manufacturing, (4) construction, (5) electricity, gas and water supply, (6) transportation, storage and communication, (7) trade, (8) finance, (9) real estate, (10) private services; and (11) government services.

2. WR stands for within-region inequalities, while BR stands for between-region inequality. 
Figure 1

Interregional Income Inequality by Population Weighted Coefficient of Variation (WCV)

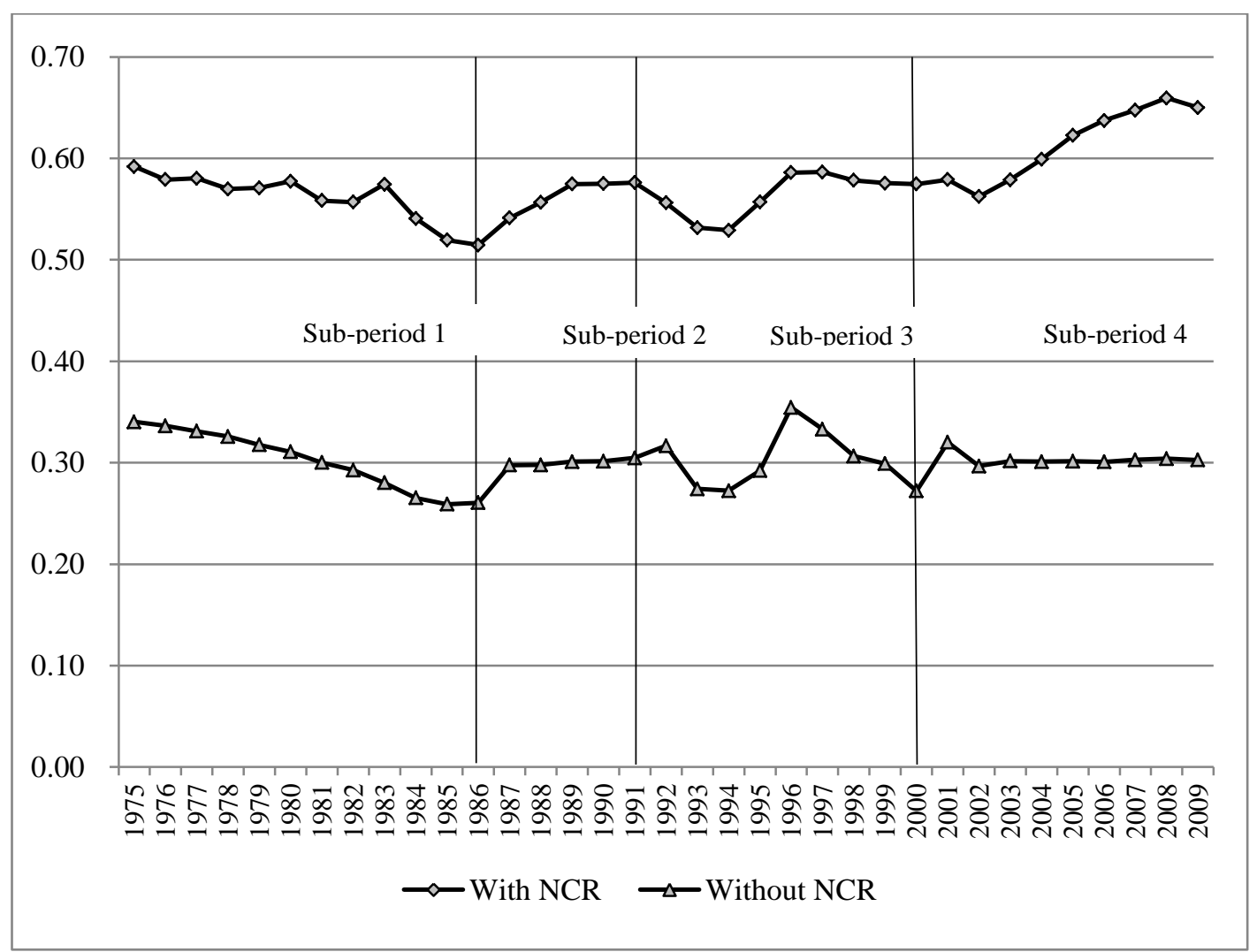

Source: Authors' calculation based on Regional Accounts of the Philippines (NSCB, various issues); and Philippine Statistical Yearbook (NSO, various issues). 
Figure 2

Interregional Income Inequality

by Theil $T$ and $L$

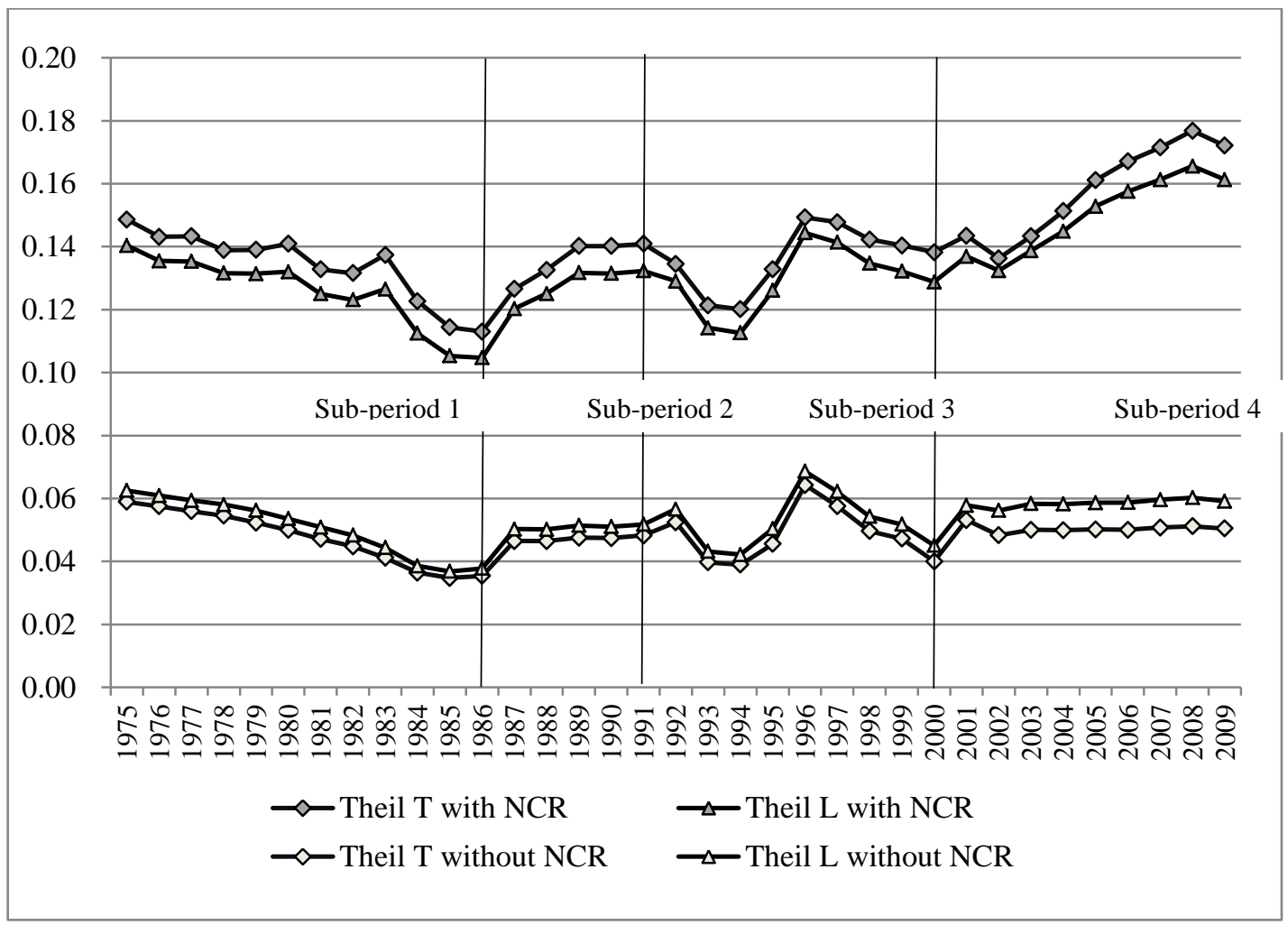

Source: Authors' calculation based on Regional Accounts of the Philippines (NSCB, various issues); and Philippine Statistical Yearbook (NSO, various issues). 
Figure 3

Interregional Income Inequality by Island Region excluding NCR

by Theil $T$



